\title{
STRUCTURAL CHANGES IN THE MARKET OF BANK DEPOSITS OF HOUSEHOLDS IN UKRAINE
}

\section{Marianna Kichurchak*}

\begin{abstract}
The purpose of the article is to identify the main factors that cause the structural changes in the market of bank deposits of households by regions of Ukraine. This is based on evaluating the spatial asymmetries in this market development in 2009-2018 by regions of Ukraine and identifying the factors that influences its structure by gross regional product (GRP) by means of the methodology of multivariate econometric modelling.

Methodology. The following scientific methods are used: analysis and synthesis, induction and deduction, comparative analysis and econometric modelling. The scope and coefficients of variation for such indicators as the share of household bank deposits by GRP, the volume of household bank deposits per capita, the structure of household bank deposits by terms in general, in national and foreign currencies are calculated. Determining the main factors for multiple regression equations influencing structural changes in the market of household bank deposits by GRP is based on the methodology of stepwise regression.

Results of the research. The spatial peculiarities of household bank deposits development in Ukraine was analysed and the reduction of its capacity was revealed due to the unfavourable socio-economic situation, the reform of the banking system and the influence of geopolitical factors. Based on the assessment of variation indicators dynamics, it was found that this market is characterised by regional asymmetries in terms of types of currencies and placement of household deposits. Regressioncorrelation equations were built, in which the shares of household deposits by regions of Ukraine ( $Y 1$, $\%$ GRP), in national currency (Y2, \% GRP) and foreign currency (Y3, \% GRP) are selected as dependent variables. The following measures are proposed to achieve positive changes in the market of household bank deposits in Ukraine: reducing unemployment; creation of favourable conditions for increasing the average monthly salary in the regions and modifying household spending to make savings; formation of an appropriate interest rate policy aimed at actively attracting temporarily available funds of the population to commercial banks.
\end{abstract}

Keywords: a market of household bank deposits, social and economic situation, indicators of variation in household bank deposits, interest rates on deposits, econometric models.

JEL Class: C10, G21, L10, 016.

\footnotetext{
* Professor, Doctor in Economics, The Department of Economy of Ukraine, Ivan Franko L'viv National University, Ukraine; https://orcid.org/0000-0002-1927-5704.
} 


\section{INTRODUCTION}

The household bank deposit market plays an important role in the functioning of the banking system in Ukraine. At the same time, this market is sensitive to changes in the socio-economic, political and security situation in the country. This means that the market of household bank deposits is dynamic and adaptive due to the influence of social, economic and political conditions and expectations of potential depositors. Taking this into account, it is necessary to assess the nature of the transformations that took place in this market in 2009-2018 by dint of the national economy being in a permanent crisis.

\section{BRIEF LITERATURE REVIEW}

The formation of theoretical and practical, scientific and methodological foundations of the household bank deposit market functioning is multi-vector. In particular, based on analysing the dynamics of bank capital, loans, deposits and using the methodology of cluster analysis, the regional peculiarities of the distribution of banking resources in the regions of Ukraine were determined (Hirna, 2012: 144-147). The features of forming the resource base of commercial banks on the basis of attracting funds from individuals after the nationalisation of "PrivatBank" were identified (Drobiazko, Liubich and Svystun, 2017: 100-102). Trends in the development of the Ukrainian banking system and the state of attracting deposits from individuals and legal entities to form the resource base of commercial banks were analysed (Mishchenko and Naumenkova, 2016: 17-19). The factors of concentration by assets and segments of the deposit market from the perspective of the Ukrainian banking system development were estimated (Rashkovan and Kornyliuk, 2015: 23). Problems of commercial banks deposit resources formation from the point of view of attracting temporarily available funds of households were structured (Popova et al., 2019).

The nature of the impact of post-crisis regulation in the EU on the cost and volume of deposits in 13 European countries was evaluated, taking into account the reliability of banking institutions (Kochaniak, 2016). Deposits in the household sector have been found to function as substitutes for equity investments (Andrzejczak and Ludwiczak, 2016: 512-515). The existence of deposits and loans convergence in relation to GDP was substantiated on the basis of a comparative analysis of households credit and deposit market development in Poland and EU countries (Utzig, 2015: 402-406). Structural peculiarities of financial savings of Polish households in 2010-2014 and the importance of bank deposits for investment activation were identified (Kulpaka, 2015: 314-317). 
The main factors of saving by households in separate countries of Central, Eastern and South-Eastern Europe were determined and the propensity of older individuals to keep funds in the form of bank deposits was specified (Beckmann et al., 2013: 11-24). An assessment of the risks of redistributing household bank deposits and the impact on them of the new Deposit guarantee rules for public and private banks in Germany was represented (Fecht et al., 2019). The relationship between interest rates, term deposits and savings accounts in the Dutch banking system has been determined (Bikker and Gerritsen, 2017). The role of deposits in the formation of the bank capital structure from the point of view of ensuring the stability of commercial banks was investigated (Franklin et al., 2015).

Taking into account the presented results of scientific research, in which the peculiarities of the impact of bank deposits on the bank capital structuring has been found out, their importance for investment, credit and deposit market development and enhancing commercial banks activities has been evaluated, the main factors of attracting temporarily available funds of households into the banking system in terms of social and economic situation in Ukraine, Poland and some countries of the EU has been revealed, it is necessary to identify the most important spatial features and regularities of structural transformations in the market of household bank deposit in the Ukrainian economy.

The purpose of the article is to identify the main factors that cause the structural changes in the market of bank deposits of households by regions of Ukraine. To achieve this goal, proceeding from the following basic assumptions and means of their proof is necessary:

- on the volatility of the structural changes in the market of household bank deposits in Ukraine at the regional level. This involves assessment of features of spatial asymmetries in this market development by regions of Ukraine (20092018). It is based on the analysis of the dynamics of scope and coefficients of variation for a number of indicators (the share of household bank deposits by gross regional product (GRP), volume of household deposits per capita, structure of household bank deposits by terms in general, in national and foreign currencies) and comparing the structure of the market of household bank deposits in Poland and Ukraine;

- the existence of a system of correlations between the household bank deposits (\% of GRP) and a combination of social and economic development indicators by regions which influence the decision of households to deposit their savings in commercial banks of Ukraine. The identification of these interconnections is based on the selection of relevant factors and their structuring by using the methodology of multivariate econometric modelling. 
This will make it possible to formulate recommendations for improving the functioning of this market in the economy of Ukraine, taking into account the peculiarities of its spatial development.

\section{THE RESEARCH METHODOLOGY}

The research methodology is based on the use of such scientific methods: analysis and synthesis - to determine the peculiarities and spatial patterns of the Ukrainian household bank deposit market development at the regional level, induction and deduction - to systematise the main factors that cause structural changes in this market, and to form scientifically based conclusions and proposals, comparative analysis - to identify differences in the respective markets in Ukraine and Poland, econometric modelling - to assess the impact of socio-economic factors on changes in the structure of household bank deposits in Ukraine by GRP.

The process of determination of multiple regression models involves the following measures:

1. Selection of a set of explanatory variables $\left(X_{i}\right)$ which may have an influence on explained variables $\left(Y_{j}\right)$. According to the purpose of this research, we will highlight the main independent variables: $X_{1}$ - employment by region, total age $15-70$ years, $\% ; X_{2}$ - unemployment (according to the ILO methodology) by region, total age $15-70$ years, $\% ; X_{3}$-unemployment (according to the ILO methodology) by region, working age, $\% ; X_{4}$ - average monthly salary by region, $\mathrm{UAH} ; X_{5}-$ real disposable income by region, $\%$ of previous year (p.y.); $X_{6}-$ GRP, $\%$ to p.y; $X_{7}-$ GRP, UAH per capita; $X_{8}$ - population expenditures by region, UAH per capita; $X_{9}$ - interest rates on household deposits (HD) by regions attracted by deposit corporations (DC), total, $\% ; X_{10}$ - interest rates on HD by regions, attracted by $\mathrm{DC}$, on demand, $\% ; X_{11}$ - interest rates on HD by regions, attracted by DC, up to 1 year, $\% ; X_{12}$ - interest rates on HD by regions, attracted by DC, from 1 year to 2 years, $\% ; X_{13}$ - interest rates on $\mathrm{HD}$ by regions, attracted by DC, over 2 years, $\% ; X_{14}$ - interest rates on HD in national currency (NC) by regions, attracted by DC, total, $\% ; X_{15}$ - interest rates on $\mathrm{HD}$ in NC by regions, attracted by $\mathrm{DC}$, on demand, $\% ; X_{16}$ - interest rates on HD in NC by regions, attracted by DC, up to 1 year, $\% ; X_{17}$ - interest rates on HD in NC by regions, attracted by DC, from 1 year to 2 years, $\% ; X_{18}$ - interest rates on HD in NC by regions, attracted by DC, over 2 years, \%; $X_{19}$ - interest rates on HD in foreign currency (FC) by regions, attracted by DC, total, $\% ; X_{20}$ - interest rates on HD in FC by regions, attracted by DC, on demand, $\% ; X_{21}$-interest rates on HD in FC by regions, attracted by DC, up to 1 year, $\% ; X_{22}$ - interest rates on HD in FC by regions, involved by DC, from 1 year to 2 years, $\% ; X_{23}$ - interest rates on HD in FC by regions, involved by DC, more than 2 years. In this case, the predicted 
variables are as follows: $Y_{1}$ - household bank deposits by region, \% GRP; $Y_{2}-$ household bank deposits in national currency by region, \% GRP; $Y_{3}$ - household bank deposits in foreign currency by region, \% GRP).

Table 1. Coefficients of Correlation between Dependent and Independent Variables, and its ranks

\begin{tabular}{|c|c|c|c|c|c|c|c|c|c|c|c|c|c|}
\hline \multirow{2}{*}{\begin{tabular}{|c|} 
De- \\
pendent \\
variable
\end{tabular}} & \multirow{2}{*}{ Indicator } & \multicolumn{12}{|c|}{ Independent variable } \\
\hline & & $X_{I}$ & $X_{2}$ & $X_{3}$ & $X_{4}$ & $X_{5}$ & $X_{6}$ & $X_{7}$ & $X_{8}$ & $X_{9}$ & $X_{10}$ & $X_{11}$ & $X_{12}$ \\
\hline \multirow[t]{2}{*}{$y_{1}$} & $\begin{array}{l}\text { Coefficient } \\
\text { of correla- } \\
\text { tion, } r_{Y_{j} X_{i}}\end{array}$ & 0.4094 & -0.3154 & -0.2312 & -0.5781 & -0.1700 & -0.3516 & -0.3808 & -0.5050 & 0.5135 & 0.4480 & 0.4534 & 0.5578 \\
\hline & Rank & 12 & 19 & 22 & 5 & 23 & 17 & 16 & 8 & 7 & 11 & 10 & 6 \\
\hline \multirow[t]{2}{*}{$y_{2}$} & $\begin{array}{l}\text { Coefficient } \\
\text { of correla- } \\
\text { tion, } r_{Y_{j} X_{i}}\end{array}$ & 0.4422 & -0.5339 & -0.5144 & -0.2336 & 0.2256 & 0.1960 & -0.0509 & -0.0610 & 0.2507 & 0.3266 & 0.1237 & -0.1375 \\
\hline & Rank & 3 & 1 & 2 & 8 & 9 & 10 & 21 & 20 & 7 & 6 & 14 & 13 \\
\hline \multirow[t]{2}{*}{$y_{3}$} & $\begin{array}{l}\text { Coefficient } \\
\text { of correla- } \\
\text { tion, } r_{Y_{j} X_{i}}\end{array}$ & 0.3108 & -0.5622 & -0.5397 & -0.3045 & 0.0156 & -0.0202 & -0.0657 & -0.0753 & 0.1610 & 0.2761 & 0.0870 & 0.0179 \\
\hline & Rank & 8 & 1 & 2 & 9 & 23 & 21 & 19 & 18 & 16 & 10 & 17 & 22 \\
\hline \multirow{2}{*}{$\begin{array}{c}\text { De- } \\
\text { pendent } \\
\text { variable }\end{array}$} & \multirow[b]{2}{*}{ Indicator } & \multicolumn{11}{|c|}{ Independent variable } & \\
\hline & & $X_{13}$ & $X_{14}$ & $X_{15}$ & $X_{16}$ & $X_{17}$ & $X_{18}$ & $X_{19}$ & $X_{20}$ & $X_{21}$ & $X_{22}$ & $X_{23}$ & \\
\hline \multirow[t]{2}{*}{$y_{1}$} & $\begin{array}{l}\text { Coefficient } \\
\text { of correla- } \\
\text { tion, } r_{Y_{j} X_{i}}\end{array}$ & 0.3171 & 0.3919 & 0.2887 & 0.4310 & 0.4943 & 0.2461 & 0.7236 & 0.6814 & 0.6904 & 0.6628 & 0.4174 & \\
\hline & Rank & 18 & 15 & 20 & 12 & 9 & 21 & 1 & 3 & 2 & 4 & 13 & \\
\hline \multirow[t]{2}{*}{$y_{2}$} & $\begin{array}{l}\text { Coefficient } \\
\text { of correla- } \\
\text { tion, } r_{Y_{j} X_{i}}\end{array}$ & 0.0469 & 0.3522 & 0.4348 & 0.1190 & 0.0777 & 0.1459 & 0.1769 & 0.0867 & 0.0679 & 0.0675 & -0.0454 & \\
\hline & Rank & 22 & 5 & 4 & 15 & 17 & 12 & 11 & 16 & 18 & 19 & 23 & \\
\hline \multirow[t]{2}{*}{$y_{3}$} & $\begin{array}{l}\text { Coefficient } \\
\text { of correla- } \\
\text { tion, } r_{Y_{j} X_{i}}\end{array}$ & 0.0312 & 0.2747 & 0.3227 & 0.2498 & 0.2401 & 0.2385 & 0.3780 & 0.3274 & 0.3408 & 0.3307 & 0.2222 & \\
\hline & Rank & 20 & 11 & 7 & 12 & 13 & 14 & 3 & 6 & 4 & 5 & 15 & \\
\hline
\end{tabular}

Source: own study based on: Regional statistics (UKRSTAT); Deposits held with deposit-taking corporations, excluding National Bank of Ukraine (National Bank of Ukraine).

2. The identification of the explanatory variables of the multiple regression equation for each explained variable $\left(Y_{1}, Y_{2}, Y_{3}\right)$ is based on the stepwise regression method (Zdrok and Lahotskyi, 2010: 162-165). In an attempt to come up with the best models, we will use such approach:

- to calculate the correlation coefficients with the dependent variables $Y_{1}-Y_{3}$ for all independent variables $X_{1}-X_{23}\left(r_{Y_{j} X_{i}}\right.$, where $j=\overline{1,3} ; i=\overline{1,23}$; table 1$)$. 
- to rank the correlation coefficients $r_{Y_{j} X_{i}}$ (by absolute value), where the first rank is assigned to the correlation coefficient whose value is the largest, the last one - the value of which is the smallest.

- to carry out the iterative process, according to which at each stage a multiple regression equation is constructed, its coefficient of determination $\left(R^{2}\right)$ is estimated and partial $F$-tests are evaluated.

For example, due to the first rank of the correlation coefficient with the resulting variable $Y_{j}$, the explanatory variable $X_{i}$ for the first regression model is chosen. If the predictor variable $X_{i}$ is appropriate according to the coefficient of determination $\left(R^{2}\right)$ and $F$-test, then among the other explanatory variables is picked out the following independent variable which has the highest rank of the correlation coefficient. So the following regression equation is constructed, its coefficient of determination $\left(R^{2}\right)$ is calculated and its partial $F$-tests are evaluated. The process is ended up when none of the independent variables included in the model is subject to removal from the multiple regression equation.

3. The obtained final multiple regression models are analysed for their adequacy according to the Fisher's test, Student's $t$-test and the absence of autocorrelation (Durbin-Watson test).

\section{THE RESEARCH RESULTS}

In 2009-2018 in the regions of Ukraine, attracting household funds to bank deposits was asymmetric (table 2). According to the dynamics of the scope of variation in household deposits by GRP, the general trend was a reduction in the regional context (except for 2011 and 2013-2014). The change in the coefficient of variation in the analysed period did not exceed the maximum allowable level (0.33), its value gradually decreased, which indicates the homogeneity of the studied times series. The spatial specificity of household bank deposits placement by GRP is associated with the process of gradual reduction of regional asymmetries, which is based on the similarity of depositors' strategies regarding determining the directions of cooperation in the field of placement of savings in banks. The differences in the strategies of the household related to decisions on bank deposits by currency. If in 2009-2018 for bank deposits of the population in the national currency by GRP the trends of gradual smoothing of regional differentiation of such a market were recorded, for deposits in foreign currency there were regional differences. Their strengthening occurred in 2014, due to the integrity violation of the bank deposit market through aggressive actions of the Russian Federation (the RF). The reasons for the heterogeneity of the market for household bank deposits in foreign currency are regional differences in the 
expectations of individuals, differentiation of conditions for socio-economic development of regions, and a propensity to save funds in foreign currency.

If we examine the indicators of household bank deposits variation in UAH per person, in general and by type of currency this market is heterogeneous (table 2), in 2009-2018 the spatial asymmetries in household bank deposits were slightly reduced, but still remain very significant. Reasons for regional differentiation of the household bank deposits market in UAH per person are caused by the nature of commercial banks network formation, the characteristics of individuals' assessment of the conditions for placing deposits in national and foreign currencies, differences in income and propensity to save. Minimising regional differentiation in this market is important for Ukraine to stimulate the development of the regional economy, which is based on improving the process of attracting investment through the banking system, increasing competition and improving the quality of banking services, increasing the attraction of new depositors to this market. To do this, it is important to pay attention to measures that are beyond the influence of the banking system of Ukraine, related to regional economic policy measures aimed at overcoming crisis phenomena at the local level, increasing employment and improving the well-being of individuals.

The behaviour of households in the Ukrainian bank deposit market in 20092018 is differentiated by terms of placement (table 3). If in 2009-2013 households showed a tendency to reduce the share of their deposits in the national currency on demand, then from 2014 and now we record the opposite process. This is an indicator that the market of household bank deposits in the national currency is influenced by factors that encourage individuals to actively use tools for rapid withdrawal of their own funds from the banking system of Ukraine. For household bank deposits in national currency on demand, the largest values of the scope and coefficient of variation were in 2014, due to differences in individuals' estimation of the geopolitical situation in the country, their perception of the reliability of banking institutions and the ability to overcome crisis phenomena with an eye to past experience. The peculiarity is that in the regional context, the value of the coefficient of variation of these household bank deposits was less than 0.33 , which indicates the uniformity of household behaviour in this market. In view of the regionality, it is important for the development of the bank deposit market to take measures aimed at reducing the share of deposits in the national currency on demand and reorienting households to favour long-term savings. On the part of commercial banks, this is due to a change in approaches to the formation of interest-rate deposit policy and encouraging depositors to extend the term of cooperation. In addition, this will indicate the restoration of confidence in the banking system of Ukraine. 
Table 2. Dynamics of indicators of variation of household bank deposits by regions of Ukraine

\begin{tabular}{|c|c|c|c|c|c|c|c|c|c|c|c|}
\hline Name of indicator & $\begin{array}{c}\text { Type of } \\
\text { variation }\end{array}$ & 2009 & 2010 & 2011 & 2012 & 2013 & 2014 & 2015 & 2016 & 2017 & 2018 \\
\hline \multirow{2}{*}{$\begin{array}{l}\text { Bank deposits of } \\
\text { households, } \\
\% \text { GRP }\end{array}$} & $\begin{array}{l}\text { Scope of } \\
\text { variation }\end{array}$ & 3.0 & 24.6 & 28.0 & 20.9 & 22.0 & 23.5 & 17.1 & 14.6 & 13.2 & 11.4 \\
\hline & & .2741 & 0.2657 & 0.2976 & 0.2331 & 0.2085 & 0.2706 & 0.2508 & 0.2503 & 0.2303 & 0.2271 \\
\hline \multirow{2}{*}{$\begin{array}{l}\text { Bank deposits of } \\
\text { households in } \\
\text { national currency, } \\
\% \text { GRP }\end{array}$} & & & 9.8 & 11.6 & 8.9 & 10.0 & 8.2 & 5.9 & 5.3 & 5.2 & 4.5 \\
\hline & $\begin{array}{l}\text { Coefficient } \\
\text { of variation }\end{array}$ & .2011 & 0.1768 & 0.2033 & 0.1524 & 0.1471 & 0.1631 & 0.1749 & 0.1639 & 0.1743 & 0.1650 \\
\hline \multirow{2}{*}{$\begin{array}{l}\text { Bank deposits of } \\
\text { households in } \\
\text { foreign currency, } \\
\% \text { GRP }\end{array}$} & $\begin{array}{l}\text { Scope } \\
\text { variati }\end{array}$ & 16.9 & 16.6 & 17.7 & 14.7 & 14.0 & 17.6 & 12.2 & 10.9 & 9.2 & 7.5 \\
\hline & $\begin{array}{l}\text { Coeffic } \\
\text { of vari }\end{array}$ & .4142 & 0.4269 & 0.4561 & 0.3773 & 0.3712 & 0.4321 & 0.4105 & 0.3834 & 0.3720 & 0.3826 \\
\hline \multirow{2}{*}{$\begin{array}{l}\text { Bank deposits of } \\
\text { households, } \\
\text { UAH per capita }\end{array}$} & $\begin{array}{l}\text { Scope } \\
\text { variati }\end{array}$ & 4813 & 18853 & 23097 & 24688 & 28925 & 34119 & 32264 & 33873 & 37537 & 39998 \\
\hline & $\begin{array}{l}\text { Coeff } \\
\text { of var }\end{array}$ & .8448 & 0.8187 & 0.8939 & 0.7881 & 0.7606 & 0.9088 & 0.8546 & 0.8173 & 0.7950 & 0.7848 \\
\hline \multirow{2}{*}{$\begin{array}{l}\text { Bank deposits of } \\
\text { households in } \\
\text { national currency, } \\
\text { UAH per capita }\end{array}$} & $\begin{array}{l}\text { Scope } \\
\text { variat }\end{array}$ & 5875 & 8553 & 10655 & 10894 & 14884 & 13604 & 12933 & 14220 & 17301 & 19826 \\
\hline & $\begin{array}{l}\text { Coefficient } \\
\text { of variation } \\
\end{array}$ & 0.6854 & 0.6678 & 0.7438 & 0.6463 & 0.6388 & 0.7204 & 0.6811 & 0.7131 & 0.7083 & 0.7032 \\
\hline \multirow{2}{*}{$\begin{array}{l}\text { Bank deposits of } \\
\text { households in } \\
\text { foreign currency, } \\
\text { UAH per capita }\end{array}$} & $\begin{array}{l}\text { Scope of } \\
\text { variation }\end{array}$ & 9327 & 10679 & 12752 & 13997 & 14236 & 20515 & 19331 & 19653 & 20236 & 20172 \\
\hline & $\begin{array}{l}\text { Coefficient } \\
\text { of variation }\end{array}$ & 1.0326 & 1.0187 & 1.0861 & 0.9650 & 0.9694 & 1.1189 & 1.0527 & 0.9317 & 0.9095 & 0.9098 \\
\hline
\end{tabular}

Source: own study based on: Gross Regional Product (2004-2018) and Demographic Situation (UKRSTAT); Deposits held with deposit-taking corporations, excluding National Bank of Ukraine (National Bank of Ukraine).

In 2009-2018, the share of household bank deposits in national currency up to 1 year was relatively stable (except for 2011, table 3 ). For the household bank deposit market these dynamics indicate the existence of well-established approaches of households to choosing this method of saving. An additional attraction was the policy of Ukrainian commercial banks, which encouraged households to place deposits for shorter periods due to higher interest rates than long-term ones. The general trend is that during the analysed period, the magnitude of the scope of variation was reduced (except in 2014) against the background of a gradual increase in the coefficient of variation. This indicates a slight increase in spatial asymmetries in the market for household bank deposits in national currency.

In 2009-2018, the share of household bank deposits in the national currency from 1 to 2 years decreased by 1.8 times, while in 2013 it was growing, from 2014 and now it is decreasing (table 3 ). The behaviour of households in this market 
segment is quite variable, which is based on a high degree of unpredictability of the socio-economic situation in Ukraine and its regions, an unfavourable evaluation of the stability of commercial banks. The peculiarity of the development for this part of the market was that during this period, the dynamics of the scope of variation was fluctuating and the value of the coefficient of variation increased. In 2009-2018, there was a reorientation of household behaviour in the regional markets of relevant bank deposits based on a rapid response to adverse scenarios for the development of the Ukrainian economy in hybrid war conditions. Positive changes in this market segment involve not only modifying the interest rate deposit policy of commercial banks, which would encourage individuals to place deposits for a period of 1 year or more, but also building confidence in the future.

The market for household bank deposits in national currency with a placement period of more than 2 years has undergone the greatest changes (table 3). In 2009-2018 the share of such bank deposits decreased by 8.1 times, and significant regional asymmetries were recorded (with separate periods of improvement). This segment of the household bank deposit market, in comparison with other parts, was the most sensitive to the influence of unfavourable geopolitical and economic factors. Restoring the long-term placement of household funds in the national currency in the banking system will require significant efforts, because it involves a number of actions aimed at forming optimistic assessments of the national currency state, ending the hybrid war with the RF and preserving Ukraine's independence, the effectiveness of government reforms and positive changes in the living conditions of individuals.

Table 3. Dynamics of indicators of variation for deposits of households by terms and by regions of Ukraine

\begin{tabular}{|c|c|c|c|c|c|c|c|c|c|c|c|c|}
\hline \multicolumn{2}{|c|}{ Name of indicator } & \begin{tabular}{|c|} 
Type of \\
variation
\end{tabular} & 2009 & 2010 & 2011 & 2012 & 2013 & 2014 & 2015 & 2016 & 2017 & 2018 \\
\hline \multirow{4}{*}{$\begin{array}{l}\text { Bank deposits } \\
\text { of households } \\
\text { in national } \\
\text { currency in- } \\
\text { cluding by } \\
\text { agreed ma- } \\
\text { turity, \% of } \\
\text { total }\end{array}$} & \multicolumn{2}{|c|}{ demand } & 34.95 & 31.52 & 29.96 & 28.88 & 25.9 & 30.78 & 39.05 & 40.96 & 44.94 & 48.94 \\
\hline & \multicolumn{2}{|c|}{ up to 1 year } & 37.88 & 30.3 & 28.61 & 35.01 & 31.56 & 36.06 & 38.4 & 34.01 & 33.24 & 38.41 \\
\hline & \multicolumn{2}{|c|}{$\begin{array}{l}\text { over } 1 \text { year and up } \\
\text { to } 2 \text { years }\end{array}$} & 21.52 & 32.47 & 35.01 & 30.71 & 39.00 & 29.48 & 16.58 & 24.42 & 21.29 & 11.95 \\
\hline & \multicolumn{2}{|c|}{ over 2 years } & 5.65 & 5.72 & 6.43 & 5.4 & 3.54 & 3.69 & 5.97 & 0.61 & 0.53 & 0.69 \\
\hline \multirow{4}{*}{$\begin{array}{l}\text { Bank deposits } \\
\text { of households } \\
\text { in foreign cur- } \\
\text { rency includ- } \\
\text { ing by agreed } \\
\text { maturity, \% } \\
\text { of total }\end{array}$} & \multicolumn{2}{|c|}{ demand } & 19.41 & 15.98 & 15.23 & 12.72 & 11.38 & 17.65 & 16.45 & 18.63 & 21.62 & 25.65 \\
\hline & \multicolumn{2}{|c|}{ up to 1 year } & 52.97 & 42.87 & 39.05 & 32.97 & 21.71 & 29.09 & 47.18 & 42.63 & 40.01 & 41.12 \\
\hline & \multicolumn{2}{|c|}{$\begin{array}{l}\text { over } 1 \text { year and up } \\
\text { to } 2 \text { years }\end{array}$} & 21.52 & 32.47 & 35.01 & 30.71 & 39 & 29.48 & 16.58 & 24.42 & 21.29 & 11.95 \\
\hline & \multicolumn{2}{|c|}{ over 2 years } & 5.60 & 6.70 & 7.27 & 9.30 & 2.96 & 3.30 & 1.85 & 1.74 & 2.02 & 1.97 \\
\hline
\end{tabular}




\begin{tabular}{|c|c|c|c|c|c|c|c|c|c|c|c|c|}
\hline \multirow{8}{*}{$\begin{array}{l}\text { Bank deposits } \\
\text { of households } \\
\text { in national } \\
\text { currency in- } \\
\text { cluding by } \\
\text { agreed ma- } \\
\text { turity, \% of } \\
\text { total }\end{array}$} & \multirow[b]{2}{*}{ demand } & \begin{tabular}{|l|} 
Scope of \\
variation
\end{tabular} & 26.6 & 14.9 & 12.1 & 13.3 & 14.0 & 35.2 & 25.1 & 22.0 & 19.4 & 17.7 \\
\hline & & $\begin{array}{l}\text { Coeffi- } \\
\text { cient of } \\
\text { variation }\end{array}$ & 0.1988 & 0.1299 & 0.1161 & 0.1163 & 0.1292 & 0.2565 & 0.1529 & 0.1360 & 0.1172 & 0.2416 \\
\hline & \multirow[b]{2}{*}{$\begin{array}{l}\text { up to } 1 \\
\text { year }\end{array}$} & $\begin{array}{l}\text { Scope of } \\
\text { variation }\end{array}$ & 19.5 & 15.2 & 11.2 & 17.5 & 17.4 & 26.1 & 18.3 & 16.9 & 15.1 & 15.1 \\
\hline & & \begin{tabular}{|l|} 
Coeffi- \\
cient of \\
variation \\
\end{tabular} & 0.1256 & 0.1130 & 0.0987 & 0.1110 & 0.1252 & 0.1408 & 0.2290 & 0.2314 & 0.2281 & 0.2292 \\
\hline & \multirow{2}{*}{$\begin{array}{l}\text { over } 1 \\
\text { year and } \\
\text { up to } 2 \\
\text { years }\end{array}$} & $\begin{array}{l}\text { Scope of } \\
\text { variation }\end{array}$ & 12.4 & 18.0 & 15.3 & 22.5 & 19.0 & 24.6 & 13.3 & 15.3 & 12.2 & 9.6 \\
\hline & & \begin{tabular}{|l|} 
Coeffi- \\
cient of \\
variation
\end{tabular} & 0.1372 & 0.1396 & 0.1209 & 0.1772 & 0.1196 & 0.1651 & 0.2657 & 0.2398 & 0.2371 & 0.2701 \\
\hline & \multirow{2}{*}{$\begin{array}{l}\text { over } 2 \\
\text { years }\end{array}$} & $\begin{array}{l}\text { Scope of } \\
\text { variation }\end{array}$ & 13.5 & 14.2 & 13.5 & 13.1 & 12.8 & 4.2 & 6.6 & 0.8 & 0.5 & 0.8 \\
\hline & & $\begin{array}{l}\text { Coeffi- } \\
\text { cient of } \\
\text { variation }\end{array}$ & 0.4845 & 0.5093 & 0.5019 & 0.5291 & 0.6099 & 0.2558 & 0.2296 & 0.3539 & 0.3278 & 0.4313 \\
\hline \multirow{8}{*}{$\begin{array}{l}\text { Bank deposits } \\
\text { of households } \\
\text { in foreign cur- } \\
\text { rency includ- } \\
\text { ing by agreed } \\
\text { maturity, \% } \\
\text { of total }\end{array}$} & \multirow[b]{2}{*}{ demand } & $\begin{array}{l}\text { Scope of } \\
\text { variation }\end{array}$ & 13.9 & 15.0 & 15.1 & 14.2 & 14.7 & 20.7 & 24.3 & 22.9 & 23.9 & 26.1 \\
\hline & & $\begin{array}{l}\text { Coeffi- } \\
\text { cient of } \\
\text { variation }\end{array}$ & 0.2046 & 0.2773 & 0.2951 & 0.3510 & 0.4027 & 0.4547 & 1.0708 & 1.0922 & 0.8933 & 0.7680 \\
\hline & \multirow[b]{2}{*}{$\begin{array}{l}\text { up to } 1 \\
\text { year }\end{array}$} & \begin{tabular}{|l|} 
Scope of \\
variation
\end{tabular} & 21.4 & 21.2 & 20.2 & 20.5 & 15.3 & 14.0 & 20.4 & 22.3 & 26.1 & 31.4 \\
\hline & & $\begin{array}{l}\text { Coeffi- } \\
\text { cient of } \\
\text { variation }\end{array}$ & 0.0845 & 0.1186 & 0.1189 & 0.1411 & 0.1709 & 0.1228 & 0.2212 & 0.2307 & 0.2468 & 0.2549 \\
\hline & \multirow{2}{*}{$\begin{array}{l}\text { over } 1 \\
\text { year and } \\
\text { up to } 2 \\
\text { years }\end{array}$} & $\begin{array}{l}\text { Scope of } \\
\text { variation }\end{array}$ & 16.6 & 21.9 & 20.6 & 25.1 & 19.2 & 27.8 & 18.0 & 32.0 & 30.7 & 26.3 \\
\hline & & \begin{tabular}{|l|} 
Coeffi- \\
cient of \\
variation
\end{tabular} & 0.2110 & 0.1706 & 0.1549 & 0.1697 & 0.0768 & 0.1370 & 0.1294 & 0.1023 & 0.1121 & 0.1305 \\
\hline & \multirow{2}{*}{$\begin{array}{l}\text { over } 2 \\
\text { years }\end{array}$} & $\begin{array}{l}\text { Scope of } \\
\text { variation }\end{array}$ & 9.7 & 11.1 & 14.7 & 21.0 & 5.3 & 5.8 & 4.1 & 2.4 & 3.1 & 2.6 \\
\hline & & $\begin{array}{l}\text { Coeffi- } \\
\text { cient of } \\
\text { variation }\end{array}$ & 0.4928 & 0.4818 & 0.5157 & 0.5756 & 1.0771 & 1.1051 & 1.0054 & 0.6251 & 0.6823 & 0.5640 \\
\hline
\end{tabular}

Source: own study based on: Deposits held with deposit-taking corporations, excluding National bank of Ukraine (National Bank of Ukraine).

The behaviour of households in the market of bank deposits in foreign currency on demand in the regional context is close to the same market in the national currency (table 3). The differences are that in 2009-2018 there was a tendency to increase the magnitude of the scope of variation and the coefficient of variation, from 2012 and now its value is higher than the maximum allowed. Taking this into account, this market segment is asymmetric, and there is an increase in the heterogeneity of the studied times series. The reasons for this are the weakening of the propensity of households to hold foreign currency savings 
in the banking system of Ukraine due to the recognition of commercial banks as insolvent, the risks of losing part of foreign currency savings, and the need to ensure the rapid availability of money due to the increased likelihood of force majeure. Unfavourable structural changes in the market for household bank deposits in foreign currency at the regional level can be partially offset by taking into account the forecasted socio-economic situation in Ukraine, and the best opportunities for saving funds in foreign currency in the banking system.

The trend to reduce the share of household bank deposits in foreign currency up to 1 year is marked by fluctuations. If before 2013 their share was reduced by almost half, then in 2014-2015 it began to grow, in 2016-2018 it was slightly reduced, but it was within 40-42\% of the total. In 2009-2018, the change in the magnitude of the scope of variation was unstable, but the value of the coefficient of variation increased being still within the range of 0.33 . The development of the market for household bank deposits in foreign currency up to 1 year at the regional level was influenced by the decision of individuals to restructure their savings in terms of currencies, the possibility of rapid withdrawal of deposits from the banking system and minimising the risks of the devaluation of the hryvnia.

Household bank savings in foreign currency for a period of 1 to 2 years were characterized by an increase of their share in the deposit portfolio in 2009-2013 and a decrease - from 2014 to now. This indicates that by 2013, households had increased their activity in this segment of the bank deposit market, thus showing their loyalty to commercial banks, from 2014, the situation was the opposite, individuals modified their behaviour in favour of withdrawing foreign currency from the banking system and kept it minimal. The situation was worsened by the fact that commercial banks in 2014 reduced interest rates on deposits in foreign currency, which indirectly encouraged depositors to keep funds in the national currency, even taking into account the risks of possible devaluation of the hryvnia. The peculiarity of the household bank deposits market in foreign currency from 1 year to 2 years was that it remained relatively homogeneous, with no significant structural asymmetries in the regional context.

The variability of household decisions to place deposits in foreign currency for more than 2 years is indicated by the dynamics of the share of such deposits in 2009-2018 and the value of the coefficient of variation. In this market segment, there are spatial asymmetries that indicate the differentiation of behaviour of Ukrainian households at the regional level through different evaluation of the current socio-economic situation. Structural changes in this segment of the market were among the largest, an increase in the share of savings in foreign currency for a period of more than 2 years will have an inertial character and this process will be influenced by the development of long-term strategies for cooperation between banking institutions and potential depositors. 
The experience of the household bank deposit market functioning in Poland shows that the stability of the banking system, the confidence of depositors in it, and the effectiveness of macroeconomic policy measures determine positive changes in the structure of such deposits by currency type (table 4). In this market, in 2010-2017, there was a steady trend towards an increase in the share of household bank deposits in their total volume. During the analysed period, it increased by 1.2 times, and the upward dynamics was observed for savings in the context of currencies. The peculiarity of the Polish market is that the share of household bank deposits in foreign currency is negligible. This is an indicator of the market's focus on using tools that encourage households to deposit their savings in Polish commercial banks in the national currency. For the Ukrainian household bank deposit market, it is also important to implement measures that would reorient the interaction of households and commercial banks in this area in favour of preference for savings in the national currency. Taking into account the Polish experience, this is a complex process in terms of time, which involves the use of a number of procedures aimed at creating a low-inflation environment, strengthening the position of the national currency in the foreign exchange market, improving the image characteristics of commercial banks and improving the deposit guarantee system for individuals.

Table 4. Structural changes in the Polish market of bank deposits, \%

\begin{tabular}{|l|c|c|c|c|c|c|c|c|}
\hline \multicolumn{1}{|c|}{ Indicator } & 2010 & 2011 & 2012 & 2013 & 2014 & 2015 & 2016 & 2017 \\
\hline Total deposits & 100 & 100 & 100 & 100 & 100 & 100 & 100 & 100 \\
\hline in national currency & 85.15 & 83.03 & 84.84 & 86.37 & 87.23 & 87.80 & 87.35 & 86.22 \\
\hline in euros & 8.52 & 9.22 & 9.48 & 8.47 & 8.51 & 8.14 & 8.57 & 9.20 \\
\hline in other foreign currencies & 6.33 & 7.75 & 5.68 & 5.15 & 4.26 & 4.06 & 4.08 & 4.58 \\
\hline Deposits of households & 51.34 & 52.69 & 55.38 & 55.83 & 57.77 & 59.46 & 60.00 & 59.70 \\
\hline in national currency & 47.32 & 48.73 & 50.94 & 51.26 & 53.24 & 54.44 & 54.71 & 53.74 \\
\hline in other foreign currencies & 4.02 & 3.95 & 4.44 & 4.57 & 4.53 & 5.02 & 5.29 & 5.95 \\
\hline of them individuals & 47.51 & 49.05 & 51.80 & 51.96 & 53.60 & 55.13 & 55.53 & 54.97 \\
\hline in national currency & 43.79 & 45.42 & 47.78 & 47.84 & 49.46 & 50.57 & 50.70 & 49.61 \\
\hline in other foreign currencies & 3.72 & 3.63 & 4.02 & 4.12 & 4.14 & 4.56 & 4.83 & 5.36 \\
\hline
\end{tabular}

Source: own study based on: Monitoring of banks 2009-2017 (Statistics Poland). 
Table 5. The Sample Regression Functions and Reporting Regression Results

\begin{tabular}{|c|c|c|c|c|c|c|}
\hline \multirow[t]{2}{*}{ Variables } & \multirow{2}{*}{$\begin{array}{l}\text { Intercept and slope } \\
\text { parameters }\end{array}$} & \multirow{2}{*}{$\begin{array}{l}\text { Standard } \\
\text { error* }\end{array}$} & \multirow{2}{*}{$\begin{array}{l}t \text {-statis- } \\
\text { tic }\end{array}$} & \multicolumn{2}{|c|}{$\begin{array}{c}\text { Confidence interval, } \\
95 \% \\
\end{array}$} & \multirow{2}{*}{$\begin{array}{l}D W \\
99 \%\end{array}$} \\
\hline & & & & low-level & high-level & \\
\hline$Y_{1}$-meet & 10.4529 & 2.1180 & 4.9352 & 8.3349 & 14.6042 & 1.767 \\
\hline variable $X_{2}$ & -0.8589 & 0.1079 & -7.9623 & -0.9668 & -0.6475 & $d_{\mathrm{L}}=1.633$ \\
\hline variable $X_{8}$ & -0.0000603 & 0.0000121 & -4.9712 & -0.0000725 & -0.0000365 & $d_{\mathrm{U}}=1.715$ \\
\hline variable $X_{12}$ & 0.6819 & 0.1028 & 6.6328 & \begin{tabular}{|l|}
0.5791 \\
\end{tabular} & 0.8835 & \\
\hline variable $X_{23}$ & 0.2803 & 0.1139 & 2.4605 & 0.1664 & 0.5035 & \\
\hline \multicolumn{2}{|c|}{ Regression statistics } & \multicolumn{5}{|c|}{ Analysis of variance } \\
\hline$R$ & 0.7302 & & $d f$ & $S S$ & $M S$ & $F$ \\
\hline$R^{2}$ & 0.5332 & Regression & 4 & 2517.8915 & 629.4729 & 61.4064 \\
\hline Normalized $R^{2}$ & 0.5245 & Residual & 215 & 2203.9501 & 10.2509 & \\
\hline $\begin{array}{l}\text { Standard er- } \\
\text { ror** }\end{array}$ & 3.2017 & Total & 219 & 4721.8416 & & \\
\hline$Y_{2}$-meet & 44.999 & 4.0038 & 11.2390 & 37.1511 & 52.8459 & 2.154 \\
\hline variable $X_{2}$ & -1.1595 & 0.3332 & -6.4488 & -1.5119 & -0.8071 & $d_{\mathrm{L}}=1.603$ \\
\hline variable $X_{4}$ & -0.0014 & 0.2592 & -5.1915 & -0.0020 & -0.0009 & $d_{\mathrm{U}}=1.746$ \\
\hline variable $X_{12}$ & -0.8585 & 0.2555 & -3.9322 & -1.2864 & -04306 & \\
\hline variable $X_{13}$ & -0.3299 & 0.0942 & -3.5030 & -0.5145 & -0.1453 & \\
\hline variable $X_{14}$ & 1.5402 & 0.2183 & 6.0273 & 1.0394 & 2.0412 & \\
\hline variable $X_{16}$ & -0.9152 & 0.0003 & -3.5314 & -1.4231 & -0.4072 & \\
\hline variable $X_{20}$ & -0.7920 & 0.1798 & -2.3769 & -1.4451 & -0.1389 & \\
\hline \multicolumn{2}{|c|}{ Regression statistics } & \multicolumn{5}{|c|}{ Analysis of variance } \\
\hline$R$ & 0.7257 & & $d f$ & $S S$ & $M S$ & $F$ \\
\hline$R^{2}$ & 0.5266 & Regression & 7 & 4896.4039 & 699.4863 & 33.6832 \\
\hline Normalized $R^{2}$ & 0.5110 & Residual & 212 & 4402.5205 & 20.7666 & \\
\hline $\begin{array}{l}\text { Standard er- } \\
\text { ror** }\end{array}$ & 4.5570 & Total & 219 & 9298.9244 & & \\
\hline$Y_{3^{-}-\text {meet }}$ & 14.3127 & 1.4390 & 9.9462 & 11.4922 & 17.1331 & 2.227 \\
\hline variable $X_{9}$ & -0.8629 & 0.1805 & -4.7815 & -1.2166 & -0.5092 & $d_{\mathrm{L}}=1.623$ \\
\hline variable $X_{12}$ & -1.1572 & 0.1204 & -9.6089 & -1.3933 & -0.9212 & $d_{\mathrm{U}}=1.725$ \\
\hline variable $X_{13}$ & -0.2121 & 0.0568 & -3.7345 & -0.3235 & -0.1008 & \\
\hline variable $X_{16}$ & 0.5281 & 0.1166 & 4.5295 & 0.2996 & 0.7566 & \\
\hline variable $X_{19}$ & 2.1718 & 0.1725 & 12.5909 & 1.8337 & 2.5099 & \\
\hline \multicolumn{2}{|c|}{ Regression statistics } & \multicolumn{4}{|c|}{ Analysis of variance } & \\
\hline$R$ & 06979 & & $d f$ & $S S$ & $M S$ & $F$ \\
\hline$R^{2}$ & 0.4871 & Regression & 5 & 1577.5158 & 315.5032 & 40.6477 \\
\hline Normalized $R^{2}$ & 0.4751 & Residual & 214 & 1661.040 & 7.7619 & \\
\hline $\begin{array}{l}\text { Standard er- } \\
\text { ror** }\end{array}$ & 2.7860 & Total & 219 & 3238.5598 & & \\
\hline
\end{tabular}

* - the slope parameters and intercept; ** - the regression. Source: own study based on: Regional statistics (UKRSTAT); Deposits held with deposit-taking corporations, excluding National Bank of Ukraine (National Bank of Ukraine). 
To determine the factors that affect the state of the household bank deposit market in the regions of Ukraine, we will characterise the influence of various factors on the structure of household deposits in general, in national and foreign currencies. Based on the stepwise regression method, multiple regression equations are specified. They describe the main factors of influence on the formation of household deposits structure in Ukraine in the context of regions as a whole, in national and foreign currencies (table 5). Statistical data for the identification of multiple regression models were taken for 27 regions of Ukraine in 2009-2018, the sample size is 220 units. Estimates of the main parameters of these econometric models indicate their adequacy according to the Fisher's test and Student's $t$-test and the absence of autocorrelation.

Economically, the regression parameters of these models can be interpreted as follows. With probability $53.32 \%$ change of household deposits ( $Y_{l}, \%$ of GRP) by regions of Ukraine is due to changes in the unemployment $\left(X_{2}\right)$, expenditures per capita $\left(X_{8}\right)$, interest rates on household deposits in the total attracted by deposit corporations for a period of 1-2 years $\left(X_{12}\right)$, and in foreign currency for a period of more than 2 years $\left(X_{23}\right)$. According to the econometric model, an increase in the unemployment rate by regions by $1 \%$ will lead to an average decrease in the share of household deposits by $0.8589 \%$ of GRP; an increase in the level of expenditures of the population by regions by $1 \mathrm{UAH}$ - on average to a decrease in the share of these deposits by $0.0000603 \%$ GRP; growth of $1 \%$ of the rate on deposits in general, attracted by deposit corporations for a period of 1 to 2 years an average increase in the share of such deposits in $0.6819 \%$ of GRP; increase by $1 \%$ of interest rates on households deposits in foreign currency for a term more than 2 years - an average increase in the share of the respective deposits by 0.2803 $\%$ of GRP.

The coefficients for factor indicators $X_{12}$ and $X_{23}$ are positive, which indicates a positive impact on the structure of household bank deposits by regions of Ukraine of such important factors as interest rates. The policy of stimulating households, which assumes their greater presence in the bank deposit market by regions of Ukraine, should take into account the attractiveness of interest rates. The coefficients for the independent variables $X_{2}$ and $X_{8}$ are negative, for the development of the household bank deposit market it is important to reduce the unemployment rate by regions of Ukraine and increase household income to activate their propensity to save.

With a probability of $52.66 \%$, changes in household bank deposits in the national currency $\left(Y_{2}, \%\right.$ of GRP) in the regional context will be caused by changes in the unemployment rate $\left(X_{2}\right)$, the average monthly salary $\left(X_{4}\right)$, interest rates on household deposits attracted by deposit corporations for a period of 1 to 2 years $\left(X_{12}\right)$ and more than 2 years $\left(X_{13}\right)$, in the national currency as a whole $\left(X_{14}\right)$ and up to 1 year $\left(X_{16}\right)$, in foreign currency on demand $\left(X_{20}\right)$. Analysis of coefficient values 
for independent variables of the regressive-correlation equation indicates that an increase in the unemployment rate by $1 \%$ will lead to a decrease in the share of household deposits in the national currency by an average of $1.1595 \%$ of GRP; increase in the average monthly salary by $1 \mathrm{UAH}$ - an average decrease of $0.0014 \%$ of GRP to household deposits in the national currency; increase by $1 \%$ of the rate on household deposits in general, attracted by deposit corporations for a period of 1 to 2 years - on average, a decrease in the share of deposits in the national currency by $0.8585 \%$ GRP; growth of $1 \%$ interest rates on deposits of households in total, attracted by deposit corporations for a period of more than 2 years - an average reduction in the share of deposits in national currency $0.3299 \%$ of GRP; increase by $1 \%$ of interest rates on deposits of households in national currency in total, attracted by deposit corporations - an average growth by $1.5402 \%$ of GRP of these deposits; an increase by $1 \%$ of interest rates on household deposits in national currency attracted by deposit corporations up to 1 year - an average reduction by $0.9152 \%$ of GRP of the relevant deposits; an increase by $1 \%$ of the rate on household deposits in foreign currency attracted by deposit corporations on demand - an average decrease by $0.7920 \%$ of the GRP of deposits in national currency.

Coefficients for independent variables $X_{2}, X_{4}, X_{12}, X_{13}, X_{16}, X_{20}$ are negative. This indicates that households are inclined to redistribute their savings in the national currency, taking into account the existing socio-economic conditions, and respond adequately to changes in interest rates. This segment of the household bank deposit market is quite variable, depending on individuals' subjective evaluations of the prospects for using their savings. A positive coefficient for factor $X_{14}$ indicates the commitment of households to expand cooperation with relevant institutions in the market of bank deposits in national currency by regions of Ukraine under favourable circumstances. Prospects for the development of this market segment are associated with improved communication with households regarding the opportunities to maximize returns on their deposits in the national currency.

With a probability of $48.71 \%$, the restructuring of deposits in foreign currency $\left(Y_{3}, \%\right.$ of GRP) will depend on changes in interest rates on household deposits in total by regions $\left(X_{9}\right)$, interest rates on deposits attracted by deposit corporations for a period of 1 to 2 years $\left(X_{12}\right)$ and more than 2 years $\left(X_{13}\right)$, in national currency up to 1 year $\left(X_{16}\right)$ and foreign currency in total $\left(X_{19}\right)$.From the built econometric model follows: if there is an increase in interest rates on deposits of households by the regions by $1 \%$, on average deposits in foreign currency will be reduced by $0.8629 \%$ of GRP; if the interest rate on deposits of households in total, attracted by deposit corporations for a period of 1 to 2 years will increase by $1 \%$, the share of deposits in foreign currency on average will be reduced by $1.1572 \%$ of GRP; if the interest rate on household deposits in total, attracted by 
deposit corporations for a period of more than 2 years, increases by $1 \%$, the share of deposits in foreign currency on average will decrease by $0.2121 \%$ GRP; if the interest rate on household deposits in national currency, attracted by deposit corporations for a period of up to 1 year, increases by $1 \%$, the share of deposits in foreign currency will increase by $0.5281 \%$ GRP; if the interest rate on household deposits in foreign currency in total, attracted by deposit corporations, increases by $1 \%$, the share of deposits in foreign currency will increase by $2.1817 \%$ of GRP.

The coefficients for the independent variables $X_{9}, X_{12}, X_{13}$ are negative, which indicates the sensitivity of the market for household bank deposits in foreign currency to changes of interest rates on deposits by regions as a whole. Households decide to give preference to deposits in foreign currency depending on the current market conditions in other segments of the household bank deposit market. Positive coefficients for factors $X_{16}$ and $X_{19}$ indicate that the formation of household savings in foreign currency is influenced by the corresponding interest policy on short-term deposits in the national currency and the current deposit rates in foreign currency. The development of this market segment will mainly depend on the conditions for attracting savings in foreign currency to the banking system by regions of Ukraine.

\section{CONCLUSIONS}

So, the activity of the household bank deposit market after the global financial and economic crisis took place in conditions of weak predictability of the current socio-economic situation in Ukraine, the reform of the institutional framework for the functioning of the national banking system and the influence of geopolitical factors. Based on the assessment of the dynamics of variation indicators, it was found that the market for household bank deposits has inherent asymmetries of regional development by currency types and placement terms. Build on studying the experience of Poland, it has been substantiated that, in Ukraine, the change in the behaviour of households in this market in order to increase the share of savings in the national currency will take a long time and will be associated with measures of macroeconomic stabilization. Due to the analysis of the main factors $\left(X_{1}-X_{23}\right)$ and dependent variables $\left(Y_{I}-Y_{3}\right)$ by using the methodology of stepwise regression, regression-correlation models are constructed. It was revealed that the structure of household bank deposits by GRP as a whole and by currency types was influenced by changes in interest rates for the terms of deposits and currency types, as well as a number of socio-economic conditions. In Ukraine, in order to restore the household bank deposit market to its post-crisis level, it is advisable to take the following measures to achieve positive changes in it: reducing unemployment; 
creating favourable conditions for increasing the average monthly salary by regions and modifying household expenditures to make savings; forming an appropriate interest rate policy aimed at more actively attracting temporarily available funds of the population to commercial banks. They are also relevant to the current crisis situation in Ukraine and the world caused by the COVID-19 pandemic, because they are related to overcoming the negative consequences of the epidemic's impact on the national economy, as well as to entering the growth trajectory.

\section{BIBLIOGRAPHY}

Andrzejczak, M. and Ludwiczak, A. (2016). Substytucja depozytów i inwestycji giełdowych w sektorze gospodarstw domowych oraz w sektorze przedsiębiorstw. Finanse, Rynki Finansowe, Ubezpieczenia, 79(1), pp. 511-521, doi: 10.18276/frfu.2016.79-40.

Beckmann, E., Hake, M. and Urvova, Ja. (2013). Determinants of Households' Savings in Central, Eastern and Southeastern Europe. Focus on European Economic Integration, Oesterreichische Nationalbank (Austrian Central Bank), 3, pp. 8-29.

Bikker, J.A. and Gerritsen, D.F. (2017). Determinants of Interest Rates on Time Deposits and Savings Accounts: Macro Factors, Bank Risk, and Account Features. International Review of Finance, 18(2), pp. 169-216, doi: 10.1111/irfi.12143.

Drobiazko, A.O., Liubich, O.O. and Svystun, A.O. (2017). Analiz rozvytku bankivskoho biznesu v Ukraini v pershii polovyni 2017 roku [Analysis of banking business development in Ukraine in the first half of 2017]. Finansy Ukrainy [Finance of Ukraine], 8, pp. 95-115, doi: 10.33763/finukr2017.08.095.

Fecht, F., Thum, S. and Weber, P. (2019). Fear, deposit insurance schemes, and deposit reallocation in the German banking system. Journal of Banking \& Finance, 105, pp. 151-165, doi: 10.1016/j.jbankfin.2019.05.005.

Franklin, A., Carletti, E. and Marquez, R. (2015). Deposits and bank capital structure. Journal of Financial Economics, 118(3), pp. 601-619, doi: 10.1016/j.jfineco.2014.11.003.

Hirna, O.Yo. (2012). Pokaznyky ta klasyfikatsii bankivskoi kontsentratsii na rehionalnomu rivni [Indicators and Classifications of Banking Concentration at Regional Level]. Rehionalna ekonomika [Regional Economy], 1, pp. 138-148.

Kochaniak, K. (2016). High value household deposits in the Eurozone: single post-crisis approach vs. national facts. Bank i Kredyt, 47(6), pp. 529-552.

Kulpaka, P. (2015). Struktura oszczędności finansowych gospodarstw domowych w Polsce w latach 2000-2014. Annales Universitatis Mariae Curie-Sctodowska, sectio H - Oeconomia, 49(4), pp. 311-318, doi: 10.17951/h.2015.49.4.311.

Mishchenko, V.I. and Naumenkova, S.V. (2016). Bankivska systema Ukrainy: problemy stanovlennia ta rozvytku [The banking system of Ukraine: problems of formation and development]. Finansy Ukrainy [Finance of Ukraine], 5, pp. 7-33.

Popova, S.M., Melnykova, O.P., Zahorska, D.M. and Nevidoma, N.V. (2019). Stan ta problemy formuvannia depozytnykh resursiv bankiv Ukrainy za rakhunok finansiv domohospodarstv [Condition and problems of formation of deposit recourses of Ukrainian banks at the expense of the finances of household]. Finansovo-kredytna diialnist: problemy teorii ta praktyky [Financial and Credit Activity: Problems of Theory and Practice], 28(1)1, pp. 46-54, doi: 10.18371/fcaptp.v1i28.163025. 
Rashkovan, V. and Kornyliuk, R. (2015). Kontsentratsiia bankivskoi systemy: mify ta fakty [Concentration of Ukraine's Banking System: Myths and Facts]. Visnyk Natsionalnoho banku Ukrainy [Visnyk of the National Bank of Ukraine], 12, pp. 6-38, doi: 10.26531/vnbu2015.234.006.

Utzig, M. (2015). Kredyty i depozyty bankowe gospodarstw domowych w Polsce na tle Unii Europejskiej. Handel Wewnętrzny, 358(5), pp. 395-409.

Zdrok, V.V. and Lahotskyi, T.Ya. (2010). Ekonometriia [Econometrics]: pidruchnyk [text book], Kyiv: Znannia.

UKRSTAT, http://www.ukrstat.gov.ua/ [Accessed 24.07.2020].

National Bank of Ukraine, https://bank.gov.ua/en/statistic/sector-financial/data-sector-financial [Accessed 25.07.2020].

Statistics Poland, https://stat.gov.pl/en/topics/economic-activities-finances/financialresults/monitoring-of-banks-2017,4,12.html [Accessed 27.07.2020]. 